\title{
Integrated Actions for Decrease and/or Elimination of Mobbing as a Psychosocial Stressor in the Organizations Accessing and Implementing Corporate Social Responsibility
}

\author{
Jolita Vveinhardt ${ }^{1}$, Martin Grancay ${ }^{2}$, Regina Andriukaitiene ${ }^{3}$ \\ ${ }^{1}$ Vytautas Magnus University \\ S. Daukanto st. 28, LT-44246, Kaunas, Lithuania \\ E-mail.Jolita.Vveinhardt@vdu.lt \\ ${ }^{2}$ Slovak University of Technology in Bratislava \\ Radlinskeho 9, 81237 Bratislava, Slovak Republic \\ E-mail.martin.grancay@stuba.sk \\ ${ }^{3}$ Lithuanian Sports University \\ Sporto st. 6, LT-44221, Kaunas, Lithuania \\ E-mail.Regina.Andriukaitiene@lsu.lt \\ cross $^{\text {ref }}{ }^{\text {http://dx.doi.org/10.5755/j01.ee.28.4.17911 }}$
}

\begin{abstract}
The purpose of this research is, having examined the expression of mobbing as a psychosocial factor in organisations accessing or implementing corporate social responsibility (CSR), to form integrated actions for the decrease and/or elimination of the phenomenon. Companies with CSR, while addressing issues of well-being of employees as an interested party, ethics and human rights, must face up to their responsibilities to prevent the employees from facing psychosocial stressors caused by mobbing and bullying, while both collaborating with organised employees' structures and accepting employees' reports on destructive relationships in working environment and taking them into consideration. Having created the instrument, an empirical research was completed conducting a survey among 1,512 respondents from 34 organisations in Lithuania that declared or did not declare CSR. It was discovered that CSR has a significant influence on the employees' approach to organisation's products, promotes greater confidence and loyalty and leads to greater personal initiative while completing tasks. However, comparing the organisations which declared and did not declare CSR, approval of the statements about psychosocial well-being is more significant in the latter ones, while in the organisations which declared CSR, orientation towards external interested subjects was revealed, and the systematic work organisation advantages possessed are not used for ensuring functional relationships between employees and employee safety against psychosocial stressors.
\end{abstract}

Keywords: Mobbing, Psychosocial Stressors, Human Resource, Corporate Social Responsibility.

\section{Introduction}

Relevance of the research. Corporate social responsibility (CSR) expands a perception of human resources as an important organizational capital and creates possibilities for integral development of the concept of employees' physical and psychological safety by coordinating interests of subjects interested in more flexibly. However, results of the research performed abroad and in Lithuania show that mobbing analysis and phenomenon prevention are given insufficient attention in the development of CSR concept.

Problem of the research. Paradox is in the fact that such misunderstandings as mobbing should not arise in employees' interrelationship in the organizations that declared CSR and are striving for CSR. Therefore, this research raises the following problematic questions: what constituents are being covered by the concept of the welfare of employees as interested subjects in the organizations that are implementing CSR? what are the links between constituents of mobbing / harassment as psychosocial stressor and corporate social responsibility? what are substantial differences between the organization that declared CSR and the one that is striving for CSR considering employees' protection from psychosocial stressors? what organizational changes are required for the elimination of problem of mobbing and harassment in employees' interrelationships?

Level of exploration of the problem. Analysis of the academic literature shows that most scientific research that is related to corporate social responsibility reveal positive sides, however, there is not much discussion on critical aspects (Wilburn K. \& Wilburn R., 2014; Reilly \& Hynan, 2014; Fort, 2014; Andre, 2015; Janssen et al., 2015; Cycyota et al., 2016; Kanashiro \& Starik, 2016; Weinzimmer \& Esken, 2016; Salciuviene et al., 2016; etc.). Analysed problem of mobbing as psychosocial stressor could be tackled by developing common values, i.e. by striving for congruence of values (Vancouver \& Schmitt, 1991; Hoffman, \& Woehr, 2006; Edwards \& Cable, 2009; 
Dolan, 2011; Ryu, 2015; Miller-Stevens et al., 2015; Spanjol et al., 2015; Peng et al., 2015; Ren \& Hamann, 2015; Erkutlu \& Chafra, 2016; Newton\& Mazur, 2016; Ciarniene et al., 2017; etc.), creating internal prevention structures (Fidalgo \& Pinuel, 2004; Psunder, 2011; etc.), organizing training of managers and employees (Ludeman, 1990; Chiaburu et al., 2010; Parl, 2014; Berber et al., 2014; Georgiadis \& Pitelis, 2016; etc.), and motivating them (Blaskova et al., 2015; Wang, 2016; Lee \& Raschke, 2016; Salami \& Ajitoni, 2016; Gkorezis \& Kastritsi, 2017; etc.). Having reviewed the research on mobbing at a workplace in the latter years, it is seen that the phenomenon is widespread in the interrelationships of employees and its elimination still remains a topical problem of organizations (Naktiyok et al., 2017; Buunk et al., 2017; Picakciefe et al., 2017; Gillen et al., 2017; Aytac et al., 2017; Samani et al., 2016; Rodic, 2016; Kowal \& Gurba, 2016; Otto \& Mamatoglu, 2015; Cakirpaloglu et al., 2015; etc.).

The purpose of this research is, having examined the expression of mobbing as a psychosocial factor in organisations accessing or implementing corporate social responsibility (CSR), to form integrated actions for decrease and/or elimination of the phenomenon.

Methods of the research. The article is prepared after a thorough analysis of academic literature. The survey of employees was carried out in organizations, and, based on the results of the research, statistical analysis of the data was performed.

\section{Theoretical Grounding}

Having analysed theoretical and empirical research of foreign and Lithuanian authors published in international scientific databases as well as documents of international organizations. During selection of the research published in this period, there was orientation towards the fact that they inter alia were based on the earlier performed research and on the presented comparison of the results. While selecting the research, first the attention was given to publications included in the WoS database. Sources for another stage of theoretical research were selected and grouped on the grounds of topicality of problems under consideration: corporate social responsibility; employees' safety and its character; social stressors; mobbing at work place and its prevention; employees' safety in the context of CSR. There were also included documents approved by international organizations, which describe corporate social responsibility and standards. In the next stage, by applying an inductive method, we applied a theoretical outline of concept of mobbing as a psychosocial stressor by implementing corporate social responsibility.

The research of Naktiyok et al. (2017) was participated by 291 public and private sector employees, who reported to be subjected to mobbing. The authors determined that employees exhibit offended responses when subjected to mobbing against possibilities to maintain their personal reputation, exhibit explicit responses when subjected to mobbing against physical health, exhibit the responses imputed to organization when subjected to mobbing against possibilities to maintain their social contacts and exhibit insidious responses when subjected to any of these mobbing types excluding mobbing against possibilities to maintain their personal reputation. Buunk et al. (2017) performed their research at secondary schools and hospitals in Uruguay $(\mathrm{N}=187)$, in striving to determine the relationship between feeling of the victim of mobbing and a perceived loss of status. The authors determined that nearly all forms of mobbing were more prevalent among hospital employees than among school employees. Picakciefe et al. (2017) analysed health care workers who work in primary health care in the city of Mugla to determine whether there is a relationship between sociodemographic characteristics, work conditions, and their level of mobbing. The authors determined that primary health care workers have high prevalence of "mobbing" exposure and state that to avoid "mobbing" at workplace, authorities and responsibilities of all employees have to be clearly determined. With reference to Gillen et al. (2017) research results, it was determined that bullying has been identified as one of the leading workplace stressors, with adverse consequences for the individual employee, groups of employees, and whole organisations. Employees who have been bullied have lower levels of job satisfaction, higher levels of anxiety and depression, and are more likely to leave their place of work. The authors state that there are needed large well-designed controlled trials of bullying prevention interventions operating on the levels of society/policy, organisation/employer, job/task and individual/job interface. According to the proposal of Gillen et al. (2017), future studies should employ validated and reliable outcome measures of bullying and a minimum of 6 months' follow-up. Aytac et al. (2017) analysed psycho-social risks, compared to other risk groups like physical, biological and chemical risks, the lesser-known area of occupational health and safety in Turkey. The authors identified the prevalence of reported workplace mobbing among a group of health workers, and assessed it in order to evaluate the association between reported mobbing and its effect on workers' health. Samani et al. (2016) researched bullying behaviour within the context of trade union organizing drives, by conducting an archival search using the Ontario Labour Relations Board database, which yielded 146 cases over a 10-year period. With reference to the research results, the authors state that managers in organizations may resort to bullying behaviour during the organizing drive, which can produce fear among employees and result in significant legal consequences. Bullying tends to start with subtle and indirect behaviours, but often escalates into more intense forms of bullying. Senior management should ensure that managers and other employees in the organization understand the potential repercussions of their bullying behaviours. Rodic (2016) performed a comparison of the legislative regulation provided by $\mathrm{BiH}$ with several European Union member states. The author compares the results of a survey conducted by the European Foundation for the Improvement of Living and Working Condition, during the year $2000 \mathrm{~m}$ in the European Union Member States, with the results of the questionnaire for employees, which he conducted in Bosnia and Herzegovina. According to the statement of Rodic (2016), Bosnia and Herzegovina is lagging behind a lot of European Union member states, both in terms of prevention of mobbing, as well as legislation, that is insufficient to regulate this 
complex issue. Kowal and Gurba (2016) determined the relationship between mobbing and professional burnout syndromes among knowledge workers in Poland, by questioning 160 Polish respondents. The results of this study confirm that phenomena of mobbing and professional burnout are very common in emerging knowledge economies. Kowal and Gurba (2016) state that knowledge workers, female and employees of small firms are especially impacted by mobbing and burnout. Otto and Mamatoglu (2015) researched a relationship between interactional justice and the outcomes organizational loyalty (affective commitment, turnover intentions), perceived job performance (self-rated performance, personal accomplishment), and mental impairment (cognitive irritation, emotional exhaustion) in an online survey of 218 employees working in the field of computer technology. Specifically, we predicted that interactional justice would heighten the quality of social exchange relationships and therefore expected perceived social support (POS) and bullying to mediate the proposed relationships. Otto and Mamatoglu (2015) determined that POS mediated the relationship between interactional justice and organizational loyalty, whereas bullying mediated the relationship between interactional justice and mental impairment. Practical implications are discussed concerning how to foster interactional justice and POS and how to weaken bullying behaviour. Cakirpaloglu et al. (2015) research results show that the results of 1,757 employees from the state and the private sector point to the $16.3 \%$ prevalence of mobbing within selected regions of the Czech Republic which corresponds to the European average. The investigation confirmed that the victims of mobbing frequently suffer from various mental health problems, especially anxiety and depression.

By assessing current research, it should be highlighted that, first, as mentioned by Branch et al. (2013), during the last two decades, scientists made a huge progress by grounding a conceptual clearness, systems and theoretical descriptions that would help to explain and tackle this very sophisticated phenomenon; however, it has often been too simplified and misunderstood. Second, Kemp (2014) noted that there is still no agreement on definition of harassment at work place, despite the fact that most descriptions cover similar criteria. Managers and human resource specialists are often facing difficulties in detection and efficient management of harassment at work place. Harassment results on objects might be very severe; they might need psychiatric treatment, and it might influence their whole life. On the other side, there is a lack of research on efficient prevention and intervention programmes. Purposeful work place policy and procedures can decrease the spread and frequency of harassment, but often competing interests of leadership might decrease impact of interventions against harassment. Despite employees' security studies accents, discussed in the context of theoretical and empirical mobbing as a psychosocial stressor as well as corporate social responsibility, are lacking a unifying attitude, a substantial link could be seen in the research performed in different aspects. However, despite recommendations that organizations should take to heart harassment at work place and more and more research is being published during latter decades, little evidence exists that there is a positive development in the management of the problem (Thirlwall, 2015).

\section{Methodology of the Research}

Having analysed scientific literature and during preparation for the first stage of the reconnaissance research, the following presumptions were formed: in Lithuanian socially responsible organizations or organizations striving for social responsibility, employees experience mobbing; employees' general feeling in respect to work and co-workers is not directly related to mobbing at work place; Lithuanian socially responsible organizations or organizations striving for social responsibility ignore prevention of mobbing as a psychosocial stressor. Based on formulated presumptions, the following categories were identified: psychosocial stressors (factors related to employees' inter-relationship FEIR; factors related to character of tasks, work content and assessment - FNCA; factors related to work organization and management - FWOM; factors related to physical working environment and conditions - FPEC); corporate social responsibility (factors related to behaviour of socially responsible organization - FOSB and socially responsible employee - FESB). Having distinguished instrument's parts and categories belonging to them, the latter ones were detailed by dividing them into criteria. For formation of the criteria validated questionnaires ,Questionnaire of diagnosing of mobbing in employees“ relationship" (Vveinhardt \& Streimikiene, 2015) and „Questionnaire of determining of management cultural level in striving to implement corporate social responsibility“ (Vveinhardt \& Andriukaitiene, 2015) were used. The following criteria were prescribed to the category of factors related to employees' inter-relationship: employees ‘ communication, employees ${ }^{`}$ isolation, employees' reputation, employees' demography, employees' creed, harm experienced by employees, employees' feeling, employees' intents. The category „Factors related to character of tasks, work content and assessment" comprises the following criteria: character of tasks, work content, work assessment. Criteria of work organization and work management were prescribed to the category of factors related to work organization and management. Criteria of physical working environment and work conditions fall under the last category of psychosocial stressors' part. The category of factors related to behaviour of socially responsible organization, which was distinguished in the part of corporate social responsibility, includes criteria of services and their quality, users' conveyance, health and safety, responsibility in environmental protection, responsibility in relationship with society, responsibility in relationship with employees. The category of factors related to behaviour of socially responsible employee comprises the following criteria: employees' responsibility to users and employees" relationship to clients. 


\section{Research Results}

A reconnaissance research was performed in two stages. During the first stage, 152 respondents (IRS) were questioned. Sample volume was selected by using a method of simple random selection, when every piece of a general set has an even and not equal to zero possibility to be selected to participate the questioning. The first stage of the reconnaissance research was intended for instrument's primal verification. The second stage of the reconnaissance research (IIRS) was participated by 301 employees from 6 organizations. We used a target selection when the research is being participated by respondents subjectively selected by researchers, which, in their opinion, best represent a general set. In this case, there is no possibility every piece of selection will be included into it. The second stage of the reconnaissance research was intended to verify and compare psychometric characteristics of the instrument after corrections performed. In the stage, conditionally named as the third, i.e. the main (IIIRS) research, 1512 employees from 34 organizations were questioned.

In the first (IRS) stage of the reconnaissance research, for example, the value of FEIR Cronbach alpha coefficient varied from 0.73 (lowest meaning) to 0.93 (highest meaning), in the second (IIRS) stage of the reconnaissance research it was $0.88-0.95$, in the third, main, (IIIRS) research it was $0.89-0.95$. As can be seen from the results presented in Table 1, without reference to sample volume, the value of Cronbach alpha coefficient increased or changed slightly (as well as the values of other indices: percentage of explained dissemination; Spearman-Brown coefficient; factorial weight L; correlation of piece totality $\mathrm{r} / \mathrm{itt})$. The number of instrument's statements during performance of correlations also varied, i.e. after the first stage of the reconnaissance research (126 statements), the instrument was supplemented during preparation for the second stage of the research (156 statements), and the instrument used in the main research consisted of 157 statements. In order to compare the results of research of other researchers on mobbing as a psychosocial stressor the Web of Science database was extensively searched. In the databases, only one research performed in Lithuania was found, which examined a relationship between harassment at work place (family doctors) and posttraumatic stress. To perform a representative research $(\mathrm{N}=323)$, IES-R questionnaire (harassment at work and post-traumatic symptoms) was used. It was determined that harassment at work place is especially widespread between Lithuanian family doctors and is related to symptoms of post-trauma stress. Strong relationship between harassment and post-trauma stress shows that harassment has significant influence on employees" mental health (Malinauskiene \& Einarsen, 2014). Therefore, the injured from harassment at work place need early and constant psychological help in striving to stimulate their mental welfare and rehabilitation (Fiabane et al., 2015). Similarly, as stated in the summarizing theoretical research (Rau \& Buyken, 2015), harassment and insecurity regarding work are identified as risk factors influencing arising of mental and somatic diseases. Besides, we should also mention other studies performed in other countries, which are directly or indirectly related to the research performed in the scope of this project. Meseguer et al. (2014) examined the role of moderating professional self-efficacy in situations of harassment at work and in aspect of independently perceived health. In the research $(\mathrm{N}=772)$, three questionnaires were used - NAQ (negative action questionnaire), GHQ-1 (general health questionnaire) and MBI (Maslach blow-out inventory). NAQ, which remains popular and adaptable (Karaahmet et al., 2013; Meseguer et al., 2014), as well as the instrument created and used in the scope of the project, were adapted to measure harassment, however, the goal of the latter was to identify negative aspects of inter-relationship. Besides, it created possibilities to segment negative actions into mobbing and harassment. Moreover, during comparison with NAQ that is adaptable in different cultural environments (Karaahmet et al., 2013), the instrument used in this project was also characterized by high internal consistency. It is confirmed by other researchers that harassment at work is a severe social stressor determining big input for both private persons and related organizations (Salin, 2015), and also that there exists a resilient relationship between psychosocial work conditions and employees' psychological welfare (Schutte et al., 2014). In the research performed by Schutte et al. (2014) internationally (34 European states), twenty five psychosocial work factors were distinguished, including work needs, needs raised by stressors, working hours, work impact and freedom, work stimulation, insecurity of work places, social support, leadership quality, discrimination and violence at work, and work and personal life balance. Relationship between these factors and welfare was researched by using a multi-stage logistic regression analysis. A strong relationship was found to exist with welfare between both genders, which is poorly assessed by the respondents: quantitative requirements, requirements to hide emotions, little possibilities for improvement, seeing no sense in work, role of conflict, low quality leadership, low social support, low feeling of society, work insecurity, low level of work stimulation, absence of work and personal life balance, discrimination and harassment. During discussion on employees ' psychological security at work in the context of corporate social responsibility, relationship of harassment with lost working hours becomes a significant evidence. Harassment as a factor of psychosocial risk is significantly related to mental health, bone and muscular system disorder having impact on employees' welfare and efficiency $(\mathrm{N}=2983$, Belgium) (Janssens et al., 2014). Besides, during formation of the instrument, significance of demographic criteria confirmed in other research was taken into consideration (for example, Montoya-Garcia et al., 2013; Mulder et al., 2014; Salin, 2015). Mulder et al. (2014) discuss sexuality in the context of social role and gender and emotions. Research $(\mathrm{N}=161$, public sector) results emphasize that in striving to prevent harassment and tackle mobbing problem, it is necessary to assess attributive and emotional processes related to differences of genders. In another research (Giorgi et al., 2013), regression analysis indicated that female employees (women) demonstrated higher level of perception on harassment than male employees. Besides, harassment is negatively related to perception of clan's and adhocracy cultures and positively related to perception of hierarchy culture. Results of moderated regression analysis 
show that manipulation in values is a significant relationship moderator between concepts of adhocracy and hierarchy cultures and harassment (Pilch \& Turska, 2015).

Results of empirical research. Empirical research was participated by 1512 employees from 34 organizations. While presenting results of empirical research, first, it is meaningful to present a significance of statistical outliers in respect of categories through a prism of sociodemographic criteria. By spreading out the research results in sociodemographic point of view, it became clear (Table 2) that in many cases employees' gender is not a statistically significant factor, despite estimates signalizing about particular differences. By applying Student's (t) criterion (t-test) with level of statistical significance 0.05 , it was determined that employees ' gender is a statistically significant factor only in aspect of behaviour of socially responsible employee. This method does not highlight deep reasons; however, analysis shows that differences become clear in behaviour of employees themselves (in case of men the estimates are negative, in case of women positive), even though in other categories statistical indices don't confirm it. Previous research that examined mobbing also highlighted the complication of assessment by gender, which was explained by differences of roles perceived by men and women. During the research, two groups of employees were distinguished: managing personnel and ordinary employees - subordinates. Differently than gender, employees ' status in organization highlighted significantly higher differences of assessment. There were determined statistically significant differences between mobbing as a psychosocial stressor and criteria of corporate social responsibility, subject to status in the enterprise. Position in the enterprise (manager or subordinate) is not statistically significant only during the assessment in aspect of the factors related to work organization and management. The same differences (managers: 0.16, employees; -0.7; t-test 4.016) were highlighted in the attitude towards corporate social responsibility. This shows not only differences in the perception, but also a critical employees' attitude towards managers' actions during both work organization and implementation of CSR initiatives. Respondents ' reactions according to specifics of the performed work didn't highlight such differences as employees' status. Work character is statistically significant only in one aspect of the six. Statistically significant reliable relationship is determined in the category of behaviour of socially responsible employee where positive and negative estimates differed significantly. Respondents performing technical and physical work assessed the statements of the category of socially responsible employee's behaviour (0.18) negatively, mean while the estimates of employees, who are giving services, show, despite insignificant, but higher acceptance (0.08, when t-test. 4.570). Having compared assessments of respondents from private and public sector, statistically significant differences were determined only in two categories. In the category of factors related to working environment and conditions, estimate of the private sector is -0.18 , and that of the public sector is positive $(0.18$, t-test -7.065$)$. Smaller, however, statistically significant differences were determined in the category of socially responsible organization's behaviour (private sector: 0.09, public sector: -0.09 , t-test 3.565). That is, despite respondents working in private sector are assess work conditions worse, they give higher approvement to CSR initiatives of own organizations, while the situation in public sector is opposite. In other categories (factors related to employees' inter-relation, factors related to character of tasks, work content and assessment, factors related to work organization and management), estimates in private sector organizations are negative (vary from -0.01 to -0.18 ), and in public sector they are positive, since values are not high (from -0.01 to 0.18 ), and differences are statistically insignificant. Respondents from public sector not only assessed CSR initiatives of own organizations more negatively than representatives of private sector, but also tended less themselves to be involved into them, and demonstrated stronger intentions to leave their organizations.

Sociodemographic indices show general tendencies, however, differences are highlighted by enterprises ' goals or objectives related to their statements in respect of CSR. Statistical outliers show (Table 3) that the organizations not striving for CSR tackle the problems of mobbing and harassment as social stressor more efficiently than the organizations that declared themselves as socially responsible or are striving for this status yet, that means that a psychosocial welfare of employees in the organizations declaring CSR and the ones striving for CSR is not a determining factor in the perceived context of CSR. On the other hand, enterprises declaring and striving for CSR have organized processes of work management and work conditions better (except physical criteria of work conditions), however, they underestimate employees ${ }^{6}$ psychosocial security from aspects of negative interpersonal relationship and management quality. Reasons for that could be searched in CSR narratives developed in the country, which are oriented towards environmental protection and relationship with society, by giving less attention to employees' inter-management and protection from psychosocial stressors. During assessment according to positive and negative z-estimates, two statistically significant tendencies are observable. First, despite zestimates are not high, the organizations declaring socially responsible activity are more focusing their attention towards responsibility in environmental protection and relationship with society, unlike the enterprises not declaring CSR. Both the organizations declaring CSR and the ones striving for CSR are tackling relationship with employees better as well, despite z-estimate being low enough (both 0.6). Second, during comparison according to such criteria as services and their quality, privity of users, employees responsibility against users, employees ${ }^{6}$ relationship with clients and attitude of employees themselves towards environmental protection, the differences are statistically insignificant. 


\begin{tabular}{|c|c|c|c|c|c|c|c|c|c|c|c|c|c|c|c|}
\hline \multirow[b]{2}{*}{ Categories } & \multicolumn{5}{|c|}{ IRS, N=152 } & \multicolumn{5}{|c|}{ IIRS, $\mathbf{N}=301 *$} & \multicolumn{5}{|c|}{ IIIRS, N=1512 } \\
\hline & $\begin{array}{c}\text { Number } \\
\text { of } \\
\text { statements }\end{array}$ & $\begin{array}{l}\text { Cronbach } \\
\text { alpha }\end{array}$ & $\begin{array}{c}\text { Factorial } \\
\text { weight } L \\
\text { (min.) }\end{array}$ & $\begin{array}{c}\text { Correlation } \\
\text { of whole } \\
\text { unit (r/itt) }\end{array}$ & $\begin{array}{c}\text { Explained } \\
\text { dispersion } \\
\%\end{array}$ & $\begin{array}{c}\text { Number } \\
\text { of } \\
\text { statements }\end{array}$ & $\begin{array}{c}\text { Cronbach } \\
\text { alpha }\end{array}$ & $\begin{array}{c}\text { Factorial } \\
\text { weight L } \\
\text { (min.) }\end{array}$ & $\begin{array}{c}\text { Correlation } \\
\text { of whole } \\
\text { unit (r/itt) }\end{array}$ & $\begin{array}{c}\text { Explained } \\
\text { dispersion } \\
\%\end{array}$ & $\begin{array}{c}\text { Number } \\
\text { of } \\
\text { statements }\end{array}$ & $\begin{array}{c}\text { Cronbach } \\
\text { alpha }\end{array}$ & $\begin{array}{c}\text { Factorial } \\
\text { weight } L \\
\text { (min.) }\end{array}$ & $\begin{array}{c}\text { Correlation } \\
\text { of whole } \\
\text { unit (r/itt) }\end{array}$ & $\begin{array}{c}\text { Explained } \\
\text { dispersion } \\
\% \\
\end{array}$ \\
\hline FEIR & 53 & $0.73-0.93$ & $0.50-0.77$ & $0.42-0.65$ & $44.33-65.37$ & 63 & $0.88-0.95$ & $0.52-0.76$ & $0.48-0.71$ & $49.66-72.02$ & 63 & $0.89-0.95$ & $0.66-0.82$ & $0.58-0.76$ & $58.80-76.23$ \\
\hline FNCA & 15 & $0.80-0.92$ & $0.64-0.76$ & $0.48-0.68$ & $49.81-68.99$ & 20 & $\begin{array}{l}0.77-0.89 \\
\end{array}$ & $0.41-0.72$ & $0.40-0.64$ & $42.31-65.17$ & 20 & $0.84-0.91$ & $\begin{array}{c}0.61-0.78 \\
\end{array}$ & $0.49-0.69$ & $50.82-69.81$ \\
\hline FWOM & 10 & $0.82-0.89$ & $0.70-0.76$ & $0.58-0.69$ & $58.96-69.19$ & 12 & $0.90-0.93$ & $0.79-0.80$ & $0.70-0.72$ & $70.55-71.94$ & 12 & $0.91-0.94$ & $0.81-0.83$ & $0.72-0.74$ & $72.54-74.08$ \\
\hline FPEC & 10 & $0.80-0.84$ & $0.56-0.63$ & $0.54-0.60$ & $56.02-61.51$ & 14 & $0.86-0.90$ & $0.52-0.68$ & $0.53-0.62$ & $55.21-62.86$ & 14 & $0.89-0.90$ & $0.62-0.73$ & $0.59-0.62$ & $60.00-62.46$ \\
\hline FOSB & 31 & $0.81-0.90$ & $0.37-0.72$ & $0.50-0.66$ & $52.39-66.95$ & 32 & $0.88-0.92$ & $0.56-0.83$ & $0.58-0.72$ & $59.41-72.80$ & 32 & $0.90-0.93$ & $0.67-0.82$ & $0.62-0.72$ & $63.14-72.78$ \\
\hline FESB & 7 & $0.68-0.89$ & $0.67-0.76$ & $0.59-0.74$ & $61.56-74.69$ & 15 & $0.85-0.95$ & $0.80-0.83$ & $0.68-0.74$ & $68.58-81.46$ & 16 & $0.81-0.95$ & $0.43-0.83$ & $0.56-0.78$ & $59.10-78.61$ \\
\hline
\end{tabular}

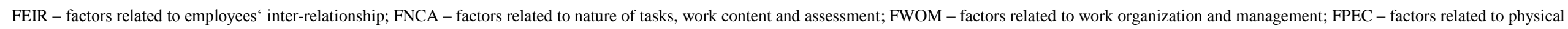
working environment and conditions; FOSB - factors related to behaviour of socially responsible organization; FESB - factor related to behaviour of socially responsible employee.

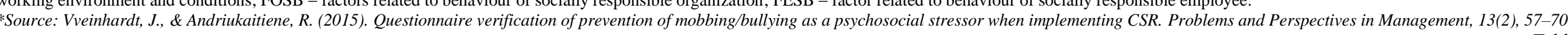

Mobbing as a Psychosocial Stressor and Corporate Social Responsibility in Respect of Employee's Gender, Work Status, Work Particularity and Sector

\begin{tabular}{|c|c|c|c|c|c|c|c|c|c|c|c|c|c|c|c|c|}
\hline \multirow{2}{*}{ Categories } & \multirow{2}{*}{$\begin{array}{c}\text { Man } \\
(\mathbf{N}=521)\end{array}$} & \multirow{2}{*}{$\begin{array}{r}\text { Woman } \\
(\mathrm{N}=991)\end{array}$} & \multicolumn{2}{|c|}{$\begin{array}{c}\begin{array}{c}\text { t-test verification } \\
\text { results }\end{array} \\
\end{array}$} & \multirow{2}{*}{$\begin{array}{c}\text { Managers } \\
(\mathbf{N}=469)\end{array}$} & \multirow{2}{*}{$\begin{array}{c}\text { Simple } \\
\text { employees, } \\
\text { specialists } \\
(\mathbf{N}=1043)\end{array}$} & \multicolumn{2}{|c|}{$\begin{array}{c}\text { t-test verification } \\
\text { results }\end{array}$} & \multirow{2}{*}{$\begin{array}{c}\text { Services } \\
(\mathbf{N}=1065)\end{array}$} & \multirow{2}{*}{$\begin{array}{c}\text { Technical, } \\
\text { physical } \\
\text { work } \\
(\mathrm{N}=447) \\
\end{array}$} & \multicolumn{2}{|c|}{$\begin{array}{c}\begin{array}{c}\text { t-test verification } \\
\text { results }\end{array} \\
\end{array}$} & \multirow{2}{*}{$\begin{array}{l}\text { Private } \\
\text { sector } \\
(\mathrm{N}=753)\end{array}$} & \multirow{2}{*}{$\begin{array}{c}\text { Public } \\
\text { sector } \\
(\mathbf{N}=759)\end{array}$} & \multicolumn{2}{|c|}{ t-test verification results } \\
\hline & & & $\mathbf{t}$ & $\mathbf{p}$ & & & $\mathbf{t}$ & $\mathbf{p}$ & & & $\mathbf{t}$ & $\mathbf{p}$ & & & $\mathbf{t}$ & $\mathbf{p}$ \\
\hline FEIR & 0.05 & -0.03 & 1.358 & 0.175 & 0.10 & -0.04 & 2.367 & $0.018^{*}$ & -0.02 & 0.06 & -1.478 & 0.140 & -0.02 & 0.02 & -0.812 & 0.417 \\
\hline FNCA & -0.06 & 0.03 & -1.617 & 0.106 & 0.16 & -0.07 & 4.016 & $0.000^{* *}$ & 0.02 & -0.04 & 0.975 & 0.330 & -0.01 & 0.01 & -0.543 & 0.587 \\
\hline FWOM & 0.05 & -0.03 & 1.449 & 0.148 & 0.00 & 0.00 & -0.035 & 0.972 & -0.02 & 0.04 & -1.040 & 0.298 & -0.04 & 0.04 & -1.448 & 0.148 \\
\hline FPEC & 0.02 & -0.01 & 0.583 & 0.560 & -0.13 & 0.06 & -3.349 & $0.001^{* * *}$ & -0.01 & 0.02 & -0.646 & 0.519 & -0.18 & 0.18 & -7.065 & $0.000^{* * *}$ \\
\hline FOSB & -0.06 & 0.03 & -1.621 & 0.105 & 0.16 & -0.07 & 4.105 & $0.000^{* *}$ & -0.01 & 0.02 & -0.406 & 0.685 & 0.09 & -0.09 & 3.565 & $0.001^{* * *}$ \\
\hline FESB & -0.08 & 0.04 & -2.188 & $0.029 *$ & 0.14 & -0.06 & 3.409 & $0.001^{* *}$ & $\begin{array}{l}0.08 \\
\end{array}$ & -0.18 & 4.570 & $0.000 * *$ & 0.03 & -0.03 & 1.040 & 0.298 \\
\hline
\end{tabular}

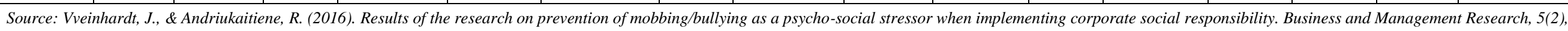
$42-57$.

Expression of Mobbing as a Psychosocial Stressor's and Corporate Social Responsibility's Sub-Categories According to Enterprise's Striving to Become (or not to Become) Socially Responsible

\begin{tabular}{|c|c|c|c|c|c|c|c|c|c|c|c|}
\hline Categories & Sub-categories & SBSR & SR & NBSR & NKSR & Categories & Sub-categories & SBSR & SR & NBSR & NKSR \\
\hline \multirow{8}{*}{ FEIR* } & Employees' communication & 0.19 & -0.15 & -0.50 & 0.02 & \multirow{2}{*}{ FWOM* } & Work organization & -0.08 & -0.09 & -0.05 & 0.07 \\
\hline & Employees' isolation & 0.13 & -0.07 & -0.29 & 0.00 & & Work management & -0.08 & -0.17 & 0.29 & 0.10 \\
\hline & Employees' reputation & 0.06 & -0.06 & -0.40 & 0.02 & \multirow{2}{*}{ FPEC* } & Work environment & -0.15 & -0.12 & 0.20 & 0.11 \\
\hline & Employees" demography & 0.18 & -0.05 & -0.33 & -0.03 & & Work conditions & -0.12 & -0.18 & 0.36 & 0.11 \\
\hline & Employees" creed & 0.12 & -0.02 & -0.25 & -0.03 & \multirow{5}{*}{ FOSB $* *$} & Services and their quality & 0.09 & 0.18 & -0.05 & -0.11 \\
\hline & Harm experienced by employees & 0.07 & -0.08 & -0.31 & 0.02 & & Privity, health and security of users & 0.11 & 0.23 & -0.17 & -0.14 \\
\hline & Employees` feeling & 0.16 & -0.14 & -0.27 & 0.01 & & Responsibility in environmental protection & 0.08 & 0.31 & -0.38 & -0.15 \\
\hline & Employees' intentions & 0.05 & -0.14 & 0.03 & 0.04 & & Responsibility in relationship with society & 0.09 & 0.30 & -0.67 & -0.13 \\
\hline \multirow{3}{*}{ FNCA* } & Character of tasks & 0.24 & -0.10 & -0.33 & -0.04 & & Responsibility in relationship with employees & 0.16 & 0.16 & -0.34 & -0.12 \\
\hline & Work content & 0.09 & -0.02 & -0.39 & -0.01 & \multirow{2}{*}{ FESB $* *$} & Employees' responsibility against users & 0.05 & 0.11 & -0.23 & -0.06 \\
\hline & Work assessment & 0.10 & -0.01 & -0.28 & -0.02 & & Employees attitude towards environmental protection & 0.03 & 0.13 & -0.10 & -0.07 \\
\hline
\end{tabular}

*Statistical outliers $\mathrm{z}<-0,25 ; \mathrm{z}>0,25$. ** Statistical outliers $\mathrm{z}>0,25 ; \mathrm{z}<-0,25$. 
That shows that CSR (even when estimates are positive) has no significant impact on quality of production and services. By comparing with the research performed in other countries (Raub \& Blunschi, 2014; Wattanakamolchai et al., 2016), it is seen that in Lithuania CSR has less influence on quality of services and products.

Further we present analysis of factors that compose mobbing / harassment (communication, employees“ isolation, employees' reputation, demographic, attacking due to aspects of creed and experienced harm) according to relationship of organizations with CSR. Though percentage differences of estimates of assent to statement of communication scale are not significant, a paradoxical situation was determined, because intensity of attacking in this field in the organizations that are not striving for CSR is lower. For example, avoidance to communicate by making indirect verbal insinuations in respect of person in the organizations declaring CSR was confirmed by $7.6 \%$ of respondents, in the organizations striving for CSR $-9.7 \%$, and in the organizations not striving for social responsibility - only $4.5 \%$. On the other hand, the least percentage of assent is for the statement that shows harassment by using means of internet communication (cyber bullying), respectively $1.4 \%, 2.4 \%$ and $0 \%$. Percentage of assent to statements shows that in the sample there were persons who faced stress factors and two main tendencies could be named. First, the weakest manifestation of attacking in communication field is in the organizations not striving for CSR (average of estimates - $1.7 \%$ ), the strongest - in the organizations striving for CSR $(5.5 \%)$, and in the organizations declaring CSR $-3.6 \%$. Second, independently on relationship of organizations with social responsibility, indirect factors are dominating, that is, demonstrative unsustaining of contact with victims by avoiding more active actions such as criticism, interruption and similar. In the organizations declaring CSR and the ones striving to become socially responsible, the actions are most distinguishing that strive to isolate associates (avoiding to communicate by making verbal insinuations and using nonverbal measures). On the other hand, in the group of the organizations striving to become socially responsible there are distinguishing factors related to interruption while talking and some aggression in processes of verbal communication, as well as harassment by using measures of nonverbal expression. Processes of employees' isolation are more highlighted in the organizations striving to become socially responsible (average in the scale $3 \%$ ) in comparison with the ones already declaring CSR (average $-2.6 \%$ ) or the ones having no such intentions (average $-0.6 \%$ ). Even though employees are missing social relationship with associates $(3.4 \%-$ in the organizations declaring CSR and $3 \%$ in the ones striving for CSR), there are highlighted deliberate actions of colleagues striving to limit their contacts, to decrease possibilities of approach to topical information. In these actions there can be envisaged some features of unfair competition. In comparison to attacking in the field of reputation, there are again differences between the organizations declaring CSR and the ones striving to become CSR: averages of expressions of assent to the statements are $3.9 \%$ and $4.4 \%$ correspondingly, when in the organizations not striving for CSR it is $0.3 \%$. Attacking in the area of reputation covers a complex of actions, by which there is a striving to understate employees ${ }^{6}$ professional competence in front of the eyes of associates and managers. As in the earlier discussed cases, higher level of assent is highlighted by coming through particular state of uncertainty when the process is not finite. In this case, we differentiate between the factors directed towards the victim by criticizing personal life (in the organizations declaring CSR - 5.6\%, in the ones striving for CSR - $5.5 \%$ ), spreading backbiting, rumour (in the organizations declaring CSR $-5.1 \%$, in the ones striving for CSR $-5.5 \%$ ) disparaging in absentia (in the organizations declaring CSR $-4.5 \%$, in the ones striving for CSR $-5.5 \%$ ), and also by constantly questioning decisions, ignoring proposals. In other words, in the organizations that don't implement changes, expression of stressors related to reputation's derogation is significantly weaker. On the other hand, expression of stressors decreases after having implemented the changes; however, stress factors exist.

By selecting victim's demographic characteristics as harassment measure, in comparison to earlier discussed results, tendencies remain unchanged (the highest negative percentage indices characterize the average of the organizations striving for CSR - $2 \%$, in the organizations declaring CSR $-1.5 \%$, in those not striving for CSR -0.3 $\%)$. However, the research results show, that intensity of such actions is lower in comparison to other factors, though family status often becomes a harassment object (in the organizations declaring CSR $-2.3 \%$, in the ones striving for CSR $-1.5 \%$ ), education (in the organizations declaring CSR $-1.7 \%$, in the ones striving for CSR $-1.8 \%$ ), and age as well (in the organizations declaring CSR $-1.4 \%$, in the ones striving for CSR $-1.8 \%$ ). This type of harassment was not identified in the organizations not striving for CSR.

Organizations striving for CSR and those declaring CSR are oriented towards higher standards of production and services, however, the research results show that harassment from employees' attitude towards work is more highlighted in the organizations striving for CSR, and estimates vary from $8.2 \%$ (sneering at fair attitude towards work) to $2.7 \%$ (sneering at religious creeds). These two positions are most typical in the organizations declaring CSR as well (5.1\% and $1.7 \%$ correspondingly). Comparing with the organizations not declaring CSR, harassment due to attitude towards work was experienced by $4.5 \%$ of respondents, harassment due to religious creeds was not recorded, however, $4.5 \%$ of respondents named they experienced attacking due to politics. Moral, physical and material harm experienced by employees almost does not differ from what is the organization's status in respect to corporate social responsibility, however, there are highlighted general tendencies. On one hand, more frequently named material losses are related to worsened health (declaring CSR $-5.4 \%$, striving for CSR - $5.2 \%$, not striving for CSR $-4.5 \%$ ), on the other hand, perceived harm is related to interference in career field (declaring CSR - 4.8 $\%$, striving for CSR $-6.4 \%$, not striving for CSR $-4.5 \%$ ). Estimates of experienced moral harm were distributed similarly as well (4.8\%, $4 \%$ and $4.5 \%$ correspondingly). Besides, employees of the organizations declaring CSR and striving for CSR more often named specially created situations when a direct material harm is being experienced $4 \%$ (in the organizations not striving for CSR estimate is less on 2 percental points). 
Percentage expressions of assent and dispraise to statements describing employees' ${ }^{6}$ feeling reveal significant differences between groups of the organizations.

Since, as mentioned above, the instrument consists of two parts (that is, "Psychosocial stressors" and "Corporate Social Responsibility"), the research results in tables 4 and 6 will be presented not at the level of individual statements, but at the level of the part of the questionnaire categories and subcategories. Interpreting the results of the research the most important results at statements level will be laconically presented in percent.

In Table 4 there are presented the averages of individual statements percentage estimates of the instrument part "Psychosocial stressors, grouped by categories and subcategories. Stress and tension are being felt mostly by employees in the organizations striving for CSR and those with undescribed situation, that is, respondents couldn't name enterprise's position in regard to social responsibility. For example, $27 \%$ of employees from the enterprises declaring CSR state that at the end of work day they feel huge fatigue, when in the enterprises not declaring CSR the percentage of such statements is only $13.6 \%$. The answers showing the experience of constant stress and tension are distributed similarly $-12 \%$ and $9 \%$ correspondingly. High estimates of assent to statements in the organizations declaring CSR show that by raising high requirements to employees, insufficient attention is given to elimination of stress sources. On the other hand, experienced stress and tension has no bigger impact on employees ' intentions related to change of work, and the share of expressions of assent to statements are close to those confirming the existence of harassment in organizations. Averages of intentions to leave work are distributed as follows: in the organizations declaring CSR $-7.5 \%$, in the organizations striving for CSR $-7.9 \%$, in the organizations not striving for CSR $-8.3 \%$. Representatives of the organizations not striving for CSR more often than others are looking for new job as an alternate variant in case they lose their job $(18.2 \%)$, and respondents from the organizations declaring CSR and striving for CSR see no possibilities for better choice (13.8\% and $11.9 \%$ correspondingly). This shows that employees of the latter organizations more appreciate available work conditions. However, the attention should be paid to insignificant differences and to the fact that in these organizations a high percentage of undecided employees remains between $13.7 \%$ and $14.7 \%$. In scientific literature, mobbing / harassment is named as organizational problem. This is also confirmed by the results of this research, in aspects of tasks, work content, assessment and other. For example, managerial personnel might use tasks based on maleficent intentions to terrorize employees. Most distinguishing are the organizations striving to become socially responsible and those declaring CSR (percentage averages $-8.8 \%$ and $6.3 \%$ correspondingly). Comparing with the research data discussed above, it should be noted that terrorizing by assigning work tasks is significantly more prevalent than other methods of pressure used to employees. In the answers of all type of organizations" employees, there dominate constantly changing new work tasks (declaring CSR - 17.8 \%, striving for CSR - 19.5\%, not striving for CSR - $15.9 \%$ ). If in the enterprises striving to become socially responsible employees are given pointless works and tasks exceeding physical possibilities $(9.4 \%)$ more often than in other organizations, then in the organizations declaring CSR these statements got lesser percentage of assent $(6.5 \%)$. The fact is meaningful that despite declaration of social responsibility values, employees also have to perform works harmful to health (declared CSR - $5.4 \%$, striving for CSR - $5.8 \%$, not striving for CSR $-4.5 \%$ ). In the scope of this research employees' reactions to work content that could be a significant stressor were assessed, and estimates are presented in Table 4. Routine, collarwork, content of which does not require creativity, and is related to intense communication, is being assessed as a stressor. Organizations not striving to become socially responsible are distinguishing by work content that fatigues employees least. In the organizations declaring CSR and striving to become CSR, work content distinguishes by the need for detailed planning, requirements to details, special preparation, and requires unduly big mental endeavour as well. On the one hand, such work content is troublesome, raising tension that threatens to be transformed into employees ' inter-conflicts or professional burn-out; on the other hand, this is some risk zone where unfair actions of managers or associates might flourish in striving to discredit employees by means of possible mistakes. Statements constitute the ways of employees' terrorizing and reputations derogation by incorrectly assessing performed work. At this point, the organizations striving to become socially responsible, strivings of which dispose with employees" actual situation, are distinguishing from a general context. These organizations are mostly characterized by the actions when work is assessed incorrectly $(16.4 \%)$, reached results are being kept silent $(15.8 \%)$, or work results are being „poached“ by another person (12.8\%). Even though the share is lower, results being kept silent is typical for the organizations declaring CSR (14.1 proc.) as well. Besides, at work there is only concentration towards stressing on mistakes $(12.7 \%)$, endeavours into work remain not estimated $(10.7 \%)$ or work is being assessed incorrectly $(10.2 \%)$. On the other hand, the research data show that general biggest problems of all organizations are the following: to keep silent positive achievements of employees, overestimated stressing of mistakes, unassessed endeavours.

Percentage estimates of respondents ' dispraise to the statements show that the biggest imperfection in work organization is in the organizations striving to become socially responsible, the ones declaring social responsibility and the organizations representatives of which couldn't name a present status. Employees from $14.9 \%$ of the organizations striving to become socially responsible and $13 \%$ of the organizations declaring CSR are missing work organization in assessment of personal possibilities. Comparing the organizations declaring CSR and those striving to become socially responsible, it is obvious that in the latter problems of work organization are more severe, and these problems are being tackled better in the organizations that are not implementing the changes related to corporate social responsibility. Though insignificantly, but these estimates show that work organization process in the CSR implementation processes 
remain underestimated and (or) unequal attention is given to all employees. Statements of work management subcategory describe quality of management and organization of processes taking place in the workplace. The research results show that quality of these processes is the better the more responsible is the organization, that is, the best situation is in the organizations declaring CSR, and the worst - in the enterprises not striving to become socially responsible. In the socially responsible organizations the following problems remain unsolved: tasks correspondence to employees' competence, exact presentation of tasks and assignments, working, creative environment. In the organizations striving to become socially responsible a package of problems comprises managers' ability to assign tasks and assignments exactly, managers' objectiveness and fairness, managers' ability to present notes correctly. Employees who couldn't name a status of their organization distinguished managers' inability to warranty internal communication properly.

Work environment was assessed as one of the stressors influencing employees' inter-relationship. As it was noted, the organizations declaring CSR often pay most attention to activities related to public communication. Since creation of suitable working environment favourable to health means responsibility of enterprises to own employees, the research results show that in this area there remain many unsolved problems; however, situation is slightly better than in the organizations not striving to become socially responsible. In the circle of problems of the organizations declaring CSR, the following work conditions dominate: temperature mode, interior adaptations to employees" needs, discomfort due to insufficient light. Representatives of the organizations striving to become socially responsible additionally named a lack of comfortable work instruments and furniture. The research results show that work and resting conditions are differing radically in the socially responsible organizations and the ones not striving to become socially responsible. The results shows such unsolved problems as resting premises, employees' supply with work instruments, prevention of industrial diseases, non-formal care in employees' security. Comparing with the organizations not striving to become socially responsible, these problems raising additional stress to employees are significantly less prevalent in the socially responsible entities.

Psychosocial Stressors According to Enterprise's Striving to Become (not Become) Socially Responsible

Table 4

\begin{tabular}{|c|c|c|c|c|c|c|c|c|c|c|c|c|c|}
\hline \multirow{2}{*}{ Categories } & \multirow{2}{*}{ Subcategories } & \multicolumn{3}{|c|}{ SR, assessment \% } & \multicolumn{3}{|c|}{ SBSR, assessment \% } & \multicolumn{3}{|c|}{ NBSR, assessment \% } & \multicolumn{3}{|c|}{ NKSR, assessment \% } \\
\hline & & D & $\mathbf{N}$ & $\mathbf{A}$ & D & $\mathbf{N}$ & $\mathbf{A}$ & D & $\mathbf{N}$ & $\mathbf{A}$ & D & $\mathbf{N}$ & $\mathbf{A}$ \\
\hline FEIR & Employees'feeling & 83.7 & 9.2 & 7.1 & 81.6 & 8.4 & 10 & 83.2 & 10.4 & 6.4 & 81.1 & 9.6 & 9.3 \\
\hline \multirow{2}{*}{ FNCA } & Work content & 62.3 & 12.7 & 24.9 & 62.8 & 11.9 & 25.2 & 73.4 & 13.3 & 13.3 & 62.3 & 13.4 & 24.3 \\
\hline & Work assessment & 73.2 & 15.7 & 11.1 & 74.5 & 12.1 & 13.5 & 78.8 & 12.5 & 8.7 & 73.6 & 15.4 & 11.1 \\
\hline \multirow{2}{*}{ FWOM } & Work organization & 11.2 & 17.7 & 71.1 & 13.3 & 15.2 & 71.6 & 8.6 & 20.9 & 70.5 & 15.7 & 19.1 & 65.1 \\
\hline & Work management & 7.8 & 17.6 & 74.5 & 8.6 & 19.4 & 72 & 13.3 & 25.3 & 61.4 & 11.4 & 23.1 & 65.4 \\
\hline \multirow{2}{*}{ FPEC } & Work environment & 12.9 & 15.6 & 71.4 & 11.3 & 13.6 & 75.1 & 16.2 & 21.1 & 62.7 & 15.9 & 17.8 & 66.2 \\
\hline & Work conditions & 15.2 & 16.6 & 68.2 & 15.7 & 16.3 & 68 & 25.6 & 19.5 & 54.9 & 20.8 & 20.1 & 59.1 \\
\hline
\end{tabular}

FEIR - factors related to employees ' inter-relationship; FNCA - factors related to nature of tasks, work content and assessment; FWOM - factors related to work organization and management; FPEC - factors related to physical working environment and conditions.

SR - socially responsible; SBSR - strives to become socially responsible; NBSR - does not strives to become socially responsible; NKSR - does not know status of own workplace in respect of social responsibility.

$\mathrm{D}$ - dispraise; $\mathrm{N}$ - neutral; A - assent.

Further, it is meaningful to compare sub-categories of stressors according to relationship of organizations with CSR (Table 5).

Table 5

Sub-Categories of Stressors According to Organization's Relation with CSR

\begin{tabular}{|l|c|c|c|c|}
\hline Sub-categories & SR & SBSR & NBSR & NKSR \\
\hline Employees' demography & $1.5 \%$ & $2.0 \%$ & $0.3 \%$ & $1.8 \%$ \\
\hline Employees' isolation & $2.3 \%$ & $3.0 \%$ & $0.6 \%$ & $3.0 \%$ \\
\hline Employees' creed & $2.7 \%$ & $5.5 \%$ & $2.7 \%$ & $3.4 \%$ \\
\hline $\begin{array}{l}\text { Employees' } \\
\text { communication }\end{array}$ & $3.6 \%$ & $5.5 \%$ & $1.7 \%$ & $5.8 \%$ \\
\hline Employees' reputation & $3.9 \%$ & $4.4 \%$ & $0.3 \%$ & $5.1 \%$ \\
\hline $\begin{array}{l}\text { Harm experienced by } \\
\text { employees }\end{array}$ & $4.3 \%$ & $4.5 \%$ & $4.2 \%$ & $4.4 \%$ \\
\hline Character of tasks & $6.3 \%$ & $8.8 \%$ & $5.8 \%$ & $6.6 \%$ \\
\hline Employees' feeling & $7.1 \%$ & $10.0 \%$ & $6.4 \%$ & $9.3 \%$ \\
\hline Employees' intentions & $7.5 \%$ & $7.9 \%$ & $8.3 \%$ & $10.3 \%$ \\
\hline Work management & $7.8 \%$ & $8.6 \%$ & $13.3 \%$ & $11.4 \%$ \\
\hline Work assessment & $11.1 \%$ & $13.5 \%$ & $8.7 \%$ & $11.1 \%$ \\
\hline Work organization & $11.2 \%$ & $13.3 \%$ & $8.6 \%$ & $15.8 \%$ \\
\hline Working environment & $13.0 \%$ & $11.3 \%$ & $16.2 \%$ & $16.0 \%$ \\
\hline Work conditions & $15.2 \%$ & $15.7 \%$ & $25.6 \%$ & $20.8 \%$ \\
\hline Work content & $24.9 \%$ & $25.2 \%$ & $13.3 \%$ & $24.3 \%$ \\
\hline
\end{tabular}

The research results show the distribution of stressful factors from the most strongly expressed ones to the least strongly expressed ones subject to organization's status. The strongest stressor in all groups of enterprises is a work content, followed by work conditions, working environment, work organization, work assessment, work management, employees' feeling, character of tasks and harm experienced by employees. The lowest values are related to employees" isolation and harassment due to demographic criteria, that is, it includes working environment, management and work organization quality that is related to psychological pressure on employees, open and indirectly expressed harassment that creates content of mobbing.

In Table 6 there are presented the averages of individual statements percentage estimates of the instrument part "Corporate Social Responsibility", grouped by categories and subcategories. The research results reveal how values of corporate social responsibility are being realized in practise - by giving services, products, communicating with clients. Thus, real situation in the socially responsible organizations essentially does not 
Jolita Vveinhardt, Martin Grancay, Regina Andriukaitiene. Integrated Actions for Decrease and/or Elimination of...

differ from the situation in the organizations not striving for social responsibility, and in some cases the problems in the latter are being solved even more efficiently. For example, in the organizations not striving for social responsibility there are more persons agreeing to the statement that the organization strives to keep promises given to clients. However, tendencies show that attention to quality of production and services does not differ according to organization's status in aspect of CSR. Meanwhile, in users' conveyance on services and production in aspect of security and health, more significant differences were noticed while comparing the enterprises declaring CSR and the ones not striving for CSR, which pay less attention to the mentioned aspects. The fact how employees themselves tend to use services and products of their enterprise could be supposed as important index. In this case, a quite considerable trust in quality of services and production was expressed by representatives of the enterprises declaring CSR (78.2\%), the highest trust was expressed by representatives of the organizations striving for social responsibility $(81.2 \%)$ and the lowest trust was in the organizations not striving to become socially responsible (61.4\%).

Corporate social responsibility in Lithuania is often related to activity in the field of environmental protection.
The research results that reflect internal reactions of employees' participating organization's production processes show that actual attention is not that clear as it should be. On the other hand, while comparing the organizations declaring CSR and those striving to become CSR with the ones that do not strive to become socially responsible, obvious differences are highlighted. For example, in such areas as financing of environmental protection ideas, ecological education, use of the technologies decreasing negative impact and other. Besides, the organizations declaring CSR and the ones striving to become socially responsible differ in their initiatives in relationship with society. The organizations declaring CSR pay biggest attention to public activities such as cooperation with non-governmental organizations and local communities, support of cultural and education projects, and least attention is given to external and internal corruption, misuse of position, patronage. However, in this case as well, situation is better by far than in the organizations that are not striving to become socially responsible. Significantly lower percentage expressions show that the organizations oriented towards external interested subjects pay significantly less attention to their employees.

Table 6

Corporate Social Responsibility According to Enterprise's Relation with CSR

\begin{tabular}{|c|c|c|c|c|c|c|c|c|c|c|c|c|}
\hline \multirow{2}{*}{ Subcategories } & \multicolumn{3}{|c|}{ SR, assessment \% } & \multicolumn{3}{|c|}{ SBSR, assessment \% } & \multicolumn{3}{|c|}{ NBSR, assessment \% } & \multicolumn{3}{|c|}{ NKSR, assessment \% } \\
\hline & D & $\mathbf{N}$ & $\mathbf{A}$ & D & $\mathbf{N}$ & $\mathbf{A}$ & D & $\mathbf{N}$ & $\mathbf{A}$ & D & $\mathbf{N}$ & $\mathbf{A}$ \\
\hline Services and their quality & 9.1 & 11.2 & 79.7 & 6.9 & 15.1 & 78 & 5.7 & 15.9 & 78.4 & 10.9 & 19.1 & 69.9 \\
\hline Users' conveyance, health and safety & 6.7 & 15.6 & 77.8 & 6.9 & 18 & 75.1 & 2.7 & 37.7 & 59.6 & 11.2 & 24.9 & 63.9 \\
\hline Responsibility in environmental protection & 8.2 & 24.6 & 67.1 & 11.3 & 24.6 & 64.1 & 20.4 & 36 & 43.5 & 15.6 & 33 & 51.3 \\
\hline Responsibility in relationship with society & 7 & 17.4 & 75.5 & 8.6 & 21.7 & 69.6 & 18.8 & 39.2 & 41.9 & 12.3 & 26.9 & 60.7 \\
\hline Responsibility in relationship with employees & 13 & 29.4 & 57.5 & 12.6 & 29 & 58.2 & 23.4 & 32.1 & 44.5 & 17.5 & 34.8 & 47.7 \\
\hline
\end{tabular}

SR - socially responsible; SBSR - strives to become socially responsible; NBSR - does not strives to become socially responsible; NKSR - does not know status of own workplace in respect of social responsibility; D - dispraise; N - neutral; A - assent.

Research results show that only slightly more than half of employees from the organizations declaring CSR and the ones striving for CSR agree to the statements that their organizations treat their employees responsibly. Despite legal responsibility being one of CSR components, only $67.8 \%$ of respondents working in Lithuanian organizations declaring CSR confirmed that requirements of legal acts protecting employees' rights are being actually followed. Besides, only about $56 \%$ of respondents confirmed that all employees have equal rights, and employees have the possibility to appeal against management decisions and prove their position. On the other hand, situation in these organizations is much better than in the enterprises that do not strive to become socially responsible.

A comparison of corporate social responsibility according to separate areas of initiatives are presented in Table 7.

Table 7

Initiative of Corporate Social Responsibility in Respect of Subcategories $(\mathrm{N}=1512)$

\begin{tabular}{|l|c|c|c|c|}
\hline Sub-categories & SR & SBSR & NBSR & NKSR \\
\hline $\begin{array}{l}\text { Responsibility in } \\
\text { relationship with } \\
\text { employees }\end{array}$ & $57.5 \%$ & $58.3 \%$ & $44.5 \%$ & $47.7 \%$ \\
\hline $\begin{array}{l}\text { Employees' } \\
\text { attitude towards }\end{array}$ & $63.0 \%$ & $64.1 \%$ & $51.8 \%$ & $58.4 \%$ \\
\hline
\end{tabular}

\begin{tabular}{|l|c|c|c|c|}
\hline Sub-categories & SR & SBSR & NBSR & NKSR \\
\hline $\begin{array}{l}\text { environmental } \\
\text { protection }\end{array}$ & & & & \\
\hline $\begin{array}{l}\text { Responsibility in } \\
\text { environmental } \\
\text { protection }\end{array}$ & $67.2 \%$ & $64.1 \%$ & $43.5 \%$ & $51.3 \%$ \\
\hline $\begin{array}{l}\text { Responsibility in } \\
\text { relationship with } \\
\text { society }\end{array}$ & $75.5 \%$ & $69.6 \%$ & $41.9 \%$ & $60.7 \%$ \\
\hline $\begin{array}{l}\text { Users' privity, } \\
\text { health and } \\
\text { security }\end{array}$ & $77.7 \%$ & $75.1 \%$ & $59.5 \%$ & $63.9 \%$ \\
\hline $\begin{array}{l}\text { Services and their } \\
\text { quality }\end{array}$ & $79.7 \%$ & $78.0 \%$ & $78.4 \%$ & $70.0 \%$ \\
\hline $\begin{array}{l}\text { Employees' } \\
\text { responsibility } \\
\text { against users }\end{array}$ & $81.4 \%$ & $86.1 \%$ & $70.9 \%$ & $79.6 \%$ \\
\hline $\begin{array}{l}\text { Employees } \\
\text { relationship with } \\
\text { clients }\end{array}$ & $83.9 \%$ & $80.4 \%$ & $80.1 \%$ & $76.8 \%$ \\
\hline
\end{tabular}

The research results show how situation differs in the organizations subject to their position in point of view of CSR. The percentages are significantly higher in the organizations declaring CSR and the ones striving for CSR. On the other hand, in the organizations there is a lack of sustainability between individual aspects of value, which are expressed in activities. Uneven distribution according to separate sub-categories highlights that the organizations do not pay equal attention to different 
activities of social responsibility. The worst situation is in relationship of the enterprises with their employees.

\section{Conclusions}

The concept of welfare of employees as interested subject should be developed in respect to prevention of mobbing / harassment as a psychosocial stressor. During the assessment of nature of this stressor, both physical and psychological guaranties of employees' welfare should be consolidated not only by institutional way, but also by the way of development of relationship of subjects interested in developing organizations ' management system. Thus, a few problematic aspects are being tackled: having extended a concept of employees ' welfare, new tasks could be formed for the organizations implementing CSR; measures of employees' security are being employed more by assessing a wide spectrum of mechanism typical to mobbing phenomenon, dynamics of interpersonal relationship and managerial aspects; expansion of concept of employees' security motivates to institutionalize additional prevention instruments in organization without limitation of inter-relationship regulation in ethical codes.

Having analysed aspects of mobbing / harassment as a psychosocial stressor and corporate social responsibility, we determined resilient connections of these constituents. Having checked and compared characteristics of methodological quality of questionnaire's parts, categories and sub-categories, it was determined that quality of content of both questionnaire's parts „Mobbing / harassment as a psychosocial stressor" and „Corporate social responsibility“ correspond to the requirements of reliability and validity raised for the questionnaires; essential differences between checked indices of quality of categories and sub-categories were not registered. Used secondary factorization with the help of the methods of Principal components and Alpha factoring showed that weights of all questionnaire's categories and subcategories are high. This confirms that the instrument is suitable for measuring a totality of the set features.

Respondents' assent to sub-categories was determined based on explained dispersion. Even the least dispersion of explained factors of all sub-categories is much higher that indicated allowable dispersion and that proves that respondents give especially strong assent to differing criteria. Prepared and verified questionnaire expands instrumental basis of quantitative CSR research.

By describing behaviour of socially responsible enterprise, the questionnaire followed traditionally named
CSR features, therefore, during statements' assessment by respondents, there were highlighted some contra-versions. For example, respondents negatively assessed working environment, work content, employees' inter-relationship, while the estimates of CSR initiatives were positive.This shows that in CSR research by involving welfare of labour force (both work content and aspects of employees ' interrelationship, where a factor of mobbing / harassment is highlighted) more detailed CSR look could be determined by revealing both problematic areas and achieved progress.

Besides, the organizations declaring CSR and the ones striving for CSR are more oriented towards environmental protection initiatives that improve the image in society, while employees' protection from psychosocial stressors almost doesn't differ in the organizations declaring and not declaring CSR - mobbing / harassment problem remains equally important. Since CSR in Lithuanian organizations determines lesser change of employees, essential differences in employees" attitude towards production, services, relationship with clients were not determined, which highlights exact imbalance and more declaring character of CSR. Existence of mobbing / harassment shows that problems in the organizations are deep-seated, therefore, changes of organizational policy are required.

First, it is advisable for personnel management professionals to review the organizations' codes of ethics and if they are missing - to include an item on protection from mobbing phenomenon; to examine the procedures of presenting and analysis of employees' complaints; second, the enterprises implementing CSR are recommended to balance priorities of relationship with subjects interested by warranting employees' protection from psychosocial stressors, thus increasing loyalty and involvement into CSR initiatives; third, a system of mobbing / harassment prevention should be implemented, where employees would participate in identification of stressors and their tackling process; the fourth, preparation of specialists should integrally connect managerial, CSR, business ethics and conflict management as well as psychosocial employees" welfare aspects with stimulation of interdiscipline of students' graduation dissertations.

Having carried out the study, further research directions are provided: the surveys should be given to employees in other that is Central and Eastern European countries; to compare the results of research carried out in Lithuania and other countries in order to assess the impact of the cultural environment.

\section{Acknowledgement}

This article is prepared on the basis of the final report of Research Council of Lithuania project "Prevention of Mobbing/ Bullying as a Psychosocial Stressor Implementing CSR".

\section{References}

Andre, R. (2015). Benefit corporations at a crossroads: as lawyers weigh in, companies weigh their options. Business Horizons, 58(2), 243-252. http://doi.org/10.1016/j.bushor.2014.12.002

Aytac, S., Dursun, S., \& Gokce, A. (2017). Mobbing as a psycho-social risk at work: a study in Turkey. Edited by: Goossens, RHM. Advances in Social \& Occupational Ergonomics. Book Series: Advances in Intelligent Systems and Computing, 487, 369-376. doi: 10.1007/978-3-319-41688-5_34 
Jolita Vveinhardt, Martin Grancay, Regina Andriukaitiene. Integrated Actions for Decrease and/or Elimination of...

Berber, N., Susnjar, G. S., Slavic, A., \& Baosic, M. (2014). Relationship between corporate social responsibility and human resource management - as new management concepts - in Central and Eastern Europe. Inzinerine EkonomikaEngineering Economics, 25(3), 360-369. http://dx.doi.org/10.5755/j01.ee.25.3.4222

Blaskova, M., Bizik, M., \& Jankal, R. (2015). Model of decision making in motivating employees and managers. Inzinerine Ekonomika-Engineering Economics, 26(5), 517-529. http://dx.doi.org/10.5755/j01.ee.26.5.8727

Branch, S., Ramsay, S., \& Barker, M. (2013). Workplace bullying, mobbing and general harassment: a review. International Journal of Management Reviews, 15(3), 280-299. doi: 10.1111/j.1468-2370.2012.00339.x

Buunk, A. P., Franco, S., Dijkstra, P., Zurriaga, R. (2017). Mobbing in schools and hospitals in Uruguay: prevalence and relation to loss of status. Journal of Interpersonal Violence, 32(5), 623-634. doi: 10.1177/0886260515625903

Cakirpaloglu, P., Smahaj, J., Dobesova Cakirpaloglu, S., \& Lemrova, S. (2015). Mobbing as a subtle form of agression in the workplace within selected regions of the Czech Republic. Edited by: Rymes, M; Gillernova, I. Psychologie Prace A Organizace, 2015, 66-76.

Chiaburu, D. S., Sawyer, K. B., \& Thoroughgood, C. N. (2010). Transferring more than learned in training: employees' and managers' (over)generalization of skills. International Journal of Selection and Assessment, 18(4), 380-393. doi: 10.1111/j.1468-2389.2010.00520.x

Ciarniene, R., Vienazindiene, M., \& Vojtovic, S. (2017). Process improvement for value creation: a case of health care organization. Inzinerine Ekonomika-Engineering Economics, 28(1), 79-87. https://doi.org/10.5755/j01. ee.28. 1.16601

Cycyota, C. S., Ferrante, C. J., \& Schroeder, J. M. (2016). Corporate social responsibility and employee volunteerism: What do the best companies do? Business Horizons, 59(3), 321-329. http://doi.org/10.1016/j.bushor.2016.01.004

Dolan, S. (2011). Coaching by values: A guide to success in the life of business and the business of life. Bloominghton, IN: iUniverse, Inc.

Edwards, J. R., \& Cable, D. M. (2009). The value of value congruence. Journal of Applied Psychology, 94(3), 654-677. doi: $10.1037 / \mathrm{a} 0014891$

Erkutlu, H., \& Chafra, J. (2016). Value congruence and commitment to change in healthcare organizations. Journal of Advances in Management Research, 13(3), 316-333. doi: 10.1108/JAMR-11-2015-0078

Fiabane, E., Flachi, D., Giorgi, I., Crepaldi, I., Candura, S.M., Mazzacane, F., \& Argentero, P. (2015). Professional outcomes and psychological health after workplace bullying: an exploratory follow-up study. Medicina del Lavoro, 106(4), 271-283.

Fidalgo, A. M., \& Pinuel, I. (2004). Cisneros scale to assess psychological harassment or mobbing at work. Psicothema, $16(4), 615-624$.

Fort, T. L. (2014). The paradox of pharmaceutical CSR: The sincerity nexus. Business Horizons, 57(2), 151-160. http://doi.org/10.1016/j.bushor.2013.10.006

Georgiadis, A., \& Pitelis, C. N. (2016). The impact of employees' and managers' training on the performance of small- and medium-sized enterprises: evidence from a randomized natural experiment in the UK service sector. British Journal of Industrial Relations, 54(2), 409-421. doi: 10.1111/bjir.12094

Gillen, P. A., Sinclair, M., Kernohan, W. G., Begley, C. M., \& Luyben, A. G. (2017). Interventions for prevention of bullying in the workplace. Cochrane Database of Systematic Reviews, 1, CD009778. doi: 10.1002/14651858. CD009778.pub2

Giorgi, G., Ando, M., Arenas, A., Shoss, M. K., \& Leon-Perez, J. M. (2013). Exploring personal and organizational determinants of workplace bullying and its prevalence in a Japanese sample. Psychology of Violence, 3(2), $185-197$. doi: $10.1037 /$ a0028049

Gkorezis, P., \& Kastritsi, A. (2017). Employee expectations and intrinsic motivation: work-related boredom as a mediator. Employee Relations, 39(1), 100-111. doi: 10.1108/ER-02-2016-0025

Hoffman, B. J., \& Woehr, D. J. (2006). A quantitative review of the relationship between person-organization fit and behavioral outcomes. Journal of Vocational Behavior, 68(3), 389-399. http://doi.org/10.1016/j.jvb.2005.08.003

Janssen, C., Sen, S., \& Bhattacharya, C.B. (2015). Corporate crises in the age of corporate social responsibility. Business Horizons, 58(2), 183-192. http://doi.org/10.1016/j.bushor.2014.11.002

Janssens, H., Clays, E., De Clercq, B., Casini, A., De Bacquer, D., Kittel, F., \& Braeckman, L. (2014). The relation between psychosocial risk factors and cause-specific long-term sickness absence. European Journal of Public Health, 24(3), 428-433. doi: 10.1093/eurpub/cku009

Kanashiro, P., \& Starik, M. (2016). Business efforts, opportunities, and limits addressing the poor: A Brazilian case study. Business Horizons, 59(5), 471-479. http://doi.org/10.1016/j.bushor.2016.03.011

Karaahmet, E., Kiran, S., Atik, L., Atasoy, N., Saracli, O., Ankarali, H., \& Konuk, N. (2013). The reliability of the Turkish version of the Negative Act Questionnaire (NAQ-TR) for measuring to mobing at work. Anadolu Psikiyatri DergisiAnatolian Journal of Psychiatry, 14(3), 275-282. doi: 10.5455/apd.38075 
Kemp, V. (2014). Antecedents, consequences and interventions for workplace bullying. Current Opinion in Psychiatry, 27(5), 364--368. doi: 10.1097/YCO.0000000000000084

Kowal, J., \& Gurba, A. (2016). Mobbing and burnout in emerging knowledge economies: an exploratory study in Poland. Edited by: Bui, TX; Sprague, RH. 2016 49th Hawaii International Conference on System Sciences (HICSS). Book Series: Proceedings of the Annual Hawaii International Conference on System Sciences, 4123-4132. doi: 10.1109/HICSS.2016.511

Lee, M. T., \& Raschke, R. L. (2016). Understanding employee motivation and organizational performance: arguments for a set-theoretic approach. Journal of Innovation \& Knowledge, 1(3), 162-169. doi: 10.1016/j.jik.2016.01.004

Ludeman, K. (1990). Instilling the worth ethic - how do you train managers to care about employees. Training and Development Journal, 44(5), 53-59.

Malinauskiene, V., \& Einarsen, S. (2014). Workplace bullying and post-traumatic stress symptoms among family physicians in Lithuania: An occupation and region specific approach. International Journal of Occupational Medicine and Environmental Health, 27(6), 919-932. doi: 10.2478/s13382-014-0328-y

Meseguer, M., Soler, M.I., \& Garcia-Izquierdo, M. (2014). The moderating role of professional self-efficacy in situations of workplace bullying and self-perceived health. Anales de Psicologia, 30(2), 573-578. doi: 10.6018/analesps.30.2.161251

Miller-Stevens, K., Taylor, J. A.., \& Morris, J. C. (2015). Are we really on the same page? An empirical examination of value congruence between public sector and nonprofit sector managers. Voluntas, 26(6), 2424-2446. doi: 10.1007/s11266-014-9514-6

Montoya-Garcia, M.E., Callejon-Ferre, A.J., Perez-Alonso, J., \& Sanchez-Hermosilla, J. (2013). Assessment of psychosocial risks faced by workers in Almeria-type greenhouses, using the Mini Psychosocial Factor method. Applied Ergonomics, 44(2), 303-311. doi: 10.1016/j.apergo.2012.08.005

Mulder, R., Pouwelse, M., Lodewijkx, H., \& Bolman, C. (2014). Workplace mobbing and bystanders' helping behaviour towards victims: the role of gender, perceived responsibility and anticipated stigma by association. International Journal of Psychology, 49(4), 304-312. doi: 10.1002/ijop.12018

Naktiyok, A., Yanik, O., \& Timuroglu, M. K. (2017). Aggression level of the employees subjected to mobbing: the differences related to individual and working life. Amme Idaresi Dergisi, 50(1), 117-177.

Newton, C. J., \& Mazur, A. K. (2016). Value congruence and job-related attitudes in a nonprofit organization: a competing values approach. International Journal of Human Resource Management, 27(10), 1013-1033. doi: 10.1080/09585192.2015.1053962

Otto, K., \& Mamatoglu, N. (2015). Why does interactional justice promote organizational loyalty, job performance, and prevent mental impairment? The role of social support and social stressors. Journal of Psychology, 149(2), $193-218$. doi: $10.1080 / 00223980.2013 .866535$

Parl, U. (2014). The role of dialogue between executives and ground-level employees mediated by MACS. Baltic Journal of Management, 9(2), 189-212. doi: 10.1108/BJM-10-2013-0153

Peng, S. Y., Pandey, S., \& Pandey, S. K. (2015). Is there a nonprofit advantage? Examining the impact of institutional context on individual-organizational value congruence. Public Administration Review, 75(4), 585-596. doi: 10.1111/puar.12357

Picakciefe, M., Acar, G., Colak, Z., \& Kilic, I. (2017). The relationship between sociodemographic characteristics, work conditions, and level of "mobbing" of health workers in primary health care. Journal of Interpersonal Violence, 32(3), 373-398. doi: 10.1177/0886260515586360

Pilch, I., \& Turska, E. (2015). Relationships between machiavellianism, organizational culture, and workplace bullying: emotional abuse from the target's and the perpetrator's perspective. Journal of Business Ethics, 128(1), 83-93. doi: 10.1007/s10551-014-2081-3

Psunder, M. (2011). Mobbing prevention and intervention strategies in educational institutions: teachers' view. New Educational Review, 26(4), 205-215.

Rau, R., \& Buyken, D. (2015). Current Status of Knowledge About Health Risk From Mental Workload: Evidence Based on a Systematic Review of Reviews. Zeitschrift fur Arbeits-und Organisationspsychologie, 59(3), 113-129. doi: 10.1026/0932-4089/a000186

Raub, S., \& Blunschi, S. (2014). The power of meaningful work: how awareness of CSR initiatives fosters task significance and positive work outcomes in service employees. Cornell Hospitality Quarterly, 55(1), 10-18 https://doi.org/10.1177/1938965513498300

Reilly, A. H., \& Hynan, K. A. (2014). Corporate communication, sustainability, and social media: It's not easy (really) being green. Business Horizons, 57(6), 747-758. http://doi.org/10.1016/j.bushor.2014.07.008

Ren, T., \& Hamann, D. J. (2015). Employee value congruence and job attitudes: the role of occupational status. Personnel Review, 44(4), 550-566. doi: 10.1108/PR-06-2013-0096 
Jolita Vveinhardt, Martin Grancay, Regina Andriukaitiene. Integrated Actions for Decrease and/or Elimination of...

Rodic, V. (2016). Mobbing in Bosnia and Herzegovina and the member states of the European Union. Edited by: Lemle, LD. International Conference on Innovative Ideas in Science (IIS2015). Book Series: IOP Conference SeriesMaterials Science and Engineering, 144, 012016. doi: 10.1088/1757-899X/144/1/012016

Ryu, G. (2015). The missing link of value congruence and its consequences: the mediating role of employees' acceptance of organizational vision. Public Personnel Management, 44(4), 473-495. doi: 10.1177/0091026015592233

Salami, S. O., \& Ajitoni, S. O. (2016). Job characteristics and burnout: the moderating roles of emotional intelligence, motivation and pay among bank employees. International Journal of Psychology, 51(5), 375-382. doi: 10.1002/ijop. 12180

Salciuviene, L., Hopeniene, R., \& Dovaliene, A. (2016). Perceived corporate social responsibility and its implementation in practice: the case of lithuanian small and medium-sized enterprises. Inzinerine Ekonomika-Engineering Economics, 27(4), 479-490. https://doi.org/10.5755/j01.ee.27.4.14713

Salin, D. (2015). Risk factors of workplace bullying for men and women: the role of the psychosocial and physical work environment. Scandinavian Journal of Psychology, 56(1), 69-77. doi: 10.1111/sjop.12169

Samnani, A. K., Boekhorst, J. A., \& Harrison, J. A. (2016). Institutional-level bullying: exploring workplace bullying during union organizing drives. Journal of Occupational and Organizational Psychology, 89(2), 377-395. doi: 10.1111/joop.12129

Schutte, S., Chastang, J.F., Malard, L., Parent-Thirion, A., Vermeylen, G., \& Niedhammer, I. (2014). Psychosocial working conditions and psychological well-being among employees in 34 European countries. International Archives of Occupational and Environmental Health, 87(8), 897-907. doi: 10.1007/s00420-014-0930-0

Spanjol, J., Tam, L., \& Tam, V. (2015). Employer-employee congruence in environmental values: an exploration of effects on job satisfaction and creativity. Journal of Business Ethics, 130(1), 117-130. doi: 10.1007/s10551-014-2208-6

Thirlwall, A. (2015). Organisational sequestering of workplace bullying: adding insult to injury. Journal of Management \& Organization, 21(2), 145-158. doi: 10.1017/jmo.2014.72

Vancouver, J., \& Schmitt, N. (1991). An exploratory examination of person-organization fit: organizational goal congruence. Personnel Psychology, 44(2), 333-352. doi: 10.1111/j.1744-6570.1991.tb00962.x

Vveinhardt, J., \& Andriukaitiene, R. (2015). Questionnaire verification of prevention of mobbing/bullying as a psychosocial stressor when implementing CSR. Problems and Perspectives in Management, 13(2), 57-70.

Vveinhardt, J., \& Andriukaitiene, R. (2016). Results of the research on prevention of mobbing/bullying as a psycho-social stressor when implementing corporate social responsibility. Business and Management Research, 5(2), $42-57$. https://doi.org/10.5430/bmr.v5n2p42

Vveinhardt, J., \& Streimikiene, D. (2015). The questionnaire for diagnosing mobbing in employees' relationships. Ekonomska Istrazivanja-Economic Research, 28(1), 441-466. doi: 10.1080/1331677X.2015.1075415

Wang, W. T. (2016). Examining the influence of the social cognitive factors and relative autonomous motivations on employees' knowledge sharing behaviors. Decision Sciences, 47(3), 404-436. doi: 10.1111/deci.12151

Wattanakamolchai, S., Singal, M., \& Murrmann, S. K. (2016). Socially responsible customers and the evaluation of service quality. Journal of Hospitality \& Tourism Research, 40(6), 715-738. https://doi.org/10.1177/1096 348014525635

Weinzimmer, L. G., \& Esken, C. A. (2016). Risky business: taking a stand on social issues. Business Horizons, 59(3), 331-337. http://doi.org/10.1016/j.bushor.2016.01.007

Wilburn, K., \& Wilburn, R. (2014). The double bottom line: profit and social benefit. Business Horizons, 57(1), 11-20. http://doi.org/10.1016/j.bushor.2013.10.001

The article has been reviewed.

Received in April, 2017; accepted in October, 2017. 